\title{
MICROFUNGI ASSOCIATED WITH LEAF LITTER DECOMPOSITION OF MICHELIA NILAGIRICA AND SEMECARPUS CORIACEA AT HAKGALA MONTANE FOREST
}

\author{
B.T.S.D.P. KANNANGARA and N. DESHAPPRIYA \\ Department of Botany, University of Kelaniya, Kelaniya
}

(Accepted: 19 January 2005)

\begin{abstract}
In Hakgala forest, Michelia nilagirica Zenk. and Semecarpus coriacea Thw. are two of the major leaf litter contributors to the forest floor. Michelia nilagirica leaves require about 2.4 years for $99 \%$ decomposition. In contrast, Semecarpus coriacea leaves require more than 20 years to complete its decomposition. Since fungi are the main biotic components which regulate the decomposition rates of leaf litter, studies on the fungal communities in both leaf litter types at various decomposition stages are of importance.
\end{abstract}

Leaves in the freshly fallen, first, second and third decomposition stages of both species were collected using the litter bag technique. Fungi were isolated from leaf material of both types using washing and plating method and the identifications were carried out using identification keys. Common as well as different fungal species were isolated from both leaf materials. Broomella acuta, Cladosporium cladosporioides, Trichoderma viride, $P$ seudobotrytis terrestris, Curvularia lunata, Cylindrocarpon didymum, Mortierella vinaceae and Nectria coccinea were the fungal species isolated in the highest frequencies. B. acuta and C. cladosporioides were present throughout the decomposition process of both types of leaf litter. Aspergillus and Penicillium species were only occasionally isolated. Hence, the present study provides an account of the fungal species associated with the decomposition of leaf litter of Hakgala montane forest.

Key words: decomposition, fungi, leaf litter

\section{INTRODUCTION}

Hakgala strict natural reserve is an upper montane rain forest in the Nuwara Eliya District. The lower elevation of this forest has 97 tree species (over $15 \mathrm{~cm} \mathrm{GBH}$ ) of which 62 are endemic. ${ }^{3}$ Some of the common tree species are Syzygium revolutum (Wight.) Walp. (Myrtaceae), Psychotria bisulcata Wight. \& Arn. (Rubiaceae), Allophylus varians (Thw.) Redlk. (Sapindaceae), Michelia nilagirica Zenk. (Magnoliaceae), Memecylon parvifolium Thw. (Melastomataceae), Eugenia mabaeoides Wight. (Myrtaceae), Syzygium rotundifolium Arn. (Myrtaceae), Cinnamomum ovalifolium Wight. (Lauraceae) and Semecarpus coriacea Thw. (Anacardiaceae). ${ }^{1}$
In forest ecosystems the annual leaf litter is a major contributor to the nutrient cycling pathway in which a major proportion of the nutrients in the net primary production is returned to the forest floor. ${ }^{2}$ The Hakgala forest floor receives a large amount of woody and nonwoody litter from various tree species including those mentioned above. The maximum total litter fall $(33 \%)$ was recorded to be in the June- July period and the minimum ( $8 \%$ ) was in the December - January period. The mean total litter fall for the forest floor per year was $7.76 \mathrm{t} \mathrm{ha}^{-1} \mathrm{y}^{-1}$ of which $80.5 \%$ was represented by non -woody materials. ${ }^{3}$

$M$. nilagirica and $S$. coriacea are two major leaf litter contributors to the forest floor which take first and third place respectively. The decomposition $\left(t_{0.99}\right)$ of the fallen dead leaves of $M$. nilagirica occurs within 2.4 years whereas decomposition of the fallen dead leaves of $S$. coriacea occurs within a period estimated to be 20.3 years.

Decomposition rates of various substrates are regulated mainly by abiotic (climate) and biotic (substrate quality, micro-organisms and soil fauna) factors. ${ }^{4,5,6}$ Climatic or abiotic factors such as rainfall, temperature and humidity are not helpful in predicting the different decomposition rates of the various types of leaf litter at the Hakgala forest. This is because these various types of litter occur together in the forest floor where differences in moisture and temperature regimes are not significant. Therefore the causative factors for the differences in the decomposition rates between $M$. nilagirica and $S$. coriacea leaf litter are the biotic factors such as substrate quality, bacteria, fungi and soil fauna.

Fungi are the most important decomposers of plant material and $75 \%$ of the

\footnotetext{
* Corresponding author
} 
decomposition of various organic substrates are done mainly by different fungal species. ${ }^{7}$ No single fungal species is able to use all components of a substrate and it is well established that a succession of different groups of fungi will appear on different substrates. ${ }^{8}$ Since fungi play a major role in litter decomposition, a comparative study on the succession of fungi on the leaf litter of $M$. nilagirica and $S$. coriacea at various decomposition stages was carried out. There have been only a few recorded studies on the fungal succession on leaf litter in Sri Lanka. This investigation has provided an account of different fungal species (communities) involved in leaf litter decomposition in a Sri Lankan montane forest as well as their changes during the decomposition gradient.

\section{METHODS AND MATERIALS}

Study plots: At the lower elevation (c.1750) of Hakgala forest five study plots $(50 \times 50 \mathrm{~m})$ were located in order to represent five replicate samples. Of these, four plots were set up in pairs with a gap of $100 \mathrm{~m}$ between the pairs and the fifth plot was set up at an elevation $10 \mathrm{~m}$ below one of the pairs of plots. For the placement of litter bags a random $1 \mathrm{~m} \times 1 \mathrm{~m}$ sub plot was marked on the forest floor in each of the five study plots (Figure 1).

Selection of the leaf litter decomposition stages: To carry out the investigation on fungi associated with the decomposition of selected leaf types it

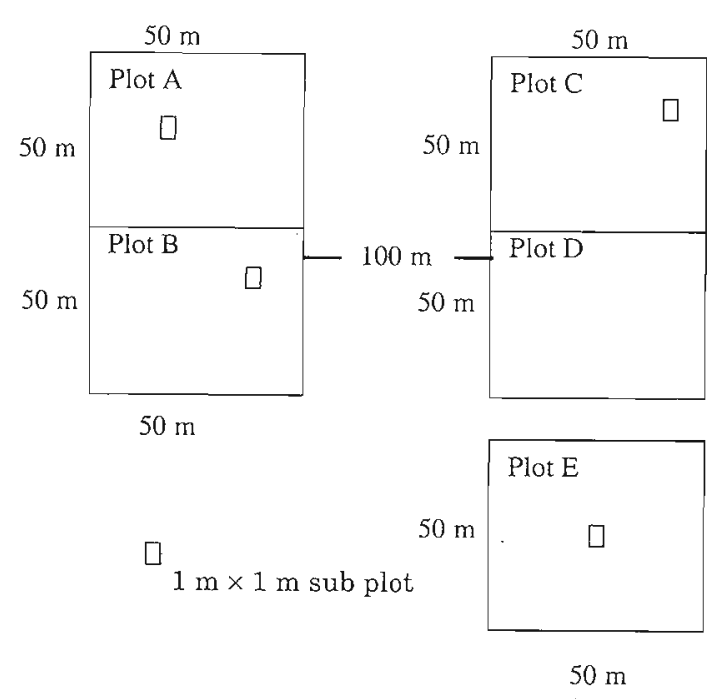

Figure 1: Layout of the sampling plots was necessary to select analogous litter decomposition stages of both leaf types $M$. nilagirica and $S$. coriacea. This was easy with respect to the leaf litter of Michelia because of the rapid decay rate (99\% decomposition occurring within 2.4 years). The selection of the decay stages for Semecarpus leaf litter posed a problem because of the slow rate of decomposition (99\% decomposition in 20.3 years). ${ }^{3}$ Therefore the following procedure was used for the two types of leaf litter.

Freshly fallen leaves of the two species were initially collected separately in large nets set up under the trees at each of the five study plots. They were then placed in large sterile polythene bags and transported to the University of Kelaniya. The following procedure was then followed.

For $M$. nilagirica: The freshly fallen leaves were placed in nylon mesh bags ( mesh size $2 \mathrm{~mm}, 6$ leaves per bag). The bags were taken to the field and placed randomly in each of the five $1 \mathrm{~m} \times 1 \mathrm{~m}$ sub plots. Thereafter these bags ( 2 bags from each sub plot) were sampled 3,6 and 9 months after placement in the field representing the $1^{\text {st }}, 2^{\text {nd }}$ and $3^{\text {rd }}$ decomposition stages respectively. At each sampling time careful, detailed visual observations were made of the decomposing leaves and descriptions of colour, texture and condition were recorded. Mass remaining (\%) was also calculated by drying the litter material in an oven at $80^{\circ} \mathrm{C}$ to a constant mass.

For S. coriacea: Using the visual observations made for each decomposition stages of Michelia leaves, the analogous stages of Semecarpus leaf litter were selected from the forest floor of each of the five study plots.

Preliminary studies on the morphology and mass remainings (dry wt.) of the $1^{\text {st }}, 2^{\text {nd }}$ and $3^{\text {rd }}$ decomposition stages of both leaf types proved that the analogous decomposition stages of both leaf types were similar.

Isolation of fungi: Using five replicate samples from each of the four decomposition stages (freshly fallen, $1^{\text {st }}, 2^{\text {nd }}$ and $3^{\text {rd }}$ ) of both leaf types, fungal isolations were carried out according to the washing and plating method. ${ }^{9}$ 
Twelve leaf disks ( $5 \mathrm{~mm}$ diameter) were obtained randomly using 4 leaves of each type ( 3 disks from each leaf) from each of the 5 replicate samples with the help of a sterilized cork borer. They were then transferred into sterilized screw capped bottles ( $100 \mathrm{ml}$ capacity) containing $25 \mathrm{ml}$ sterilized distilled water and shaken at 300 revolutions/min for $2 \mathrm{~min}$. This washing process was repeated 20 times using $25 \mathrm{ml}$ portions of sterilized distilled water for each washing. It was determined that 20 repeated washings were required for the efficient removal of surface contaminants associated with leaf material of both plant species. ${ }^{10}$ The excess water was then removed from the disks by blotting with sterile filter papers.

Two $(1 \mathrm{~mm})$ pieces of leaf were then taken from each disk using a sterilized scalpel (total of $241 \mathrm{~mm}$ leaf particles from each of the five replicate samples). Leaf particles were then plated (one particle per plate) on $2 \%$ malt extract agar supplemented with $0.01 \%$ streptomycin sulphate. The plates containing leaf particles were incubated at room temperature $\left(30^{\circ} \mathrm{C}\right)$ for $7-10 \mathrm{~d}$. Using a dissecting microscope (Olympus, 313368) fungi growing from the leaf particles were isolated into pure cultures using the same medium (2\% MEA) without antibiotics. Using the sticky tape method ${ }^{11}$ and by preparing slide cultures the isolated fungal species were identified using fungal identification keys. ${ }^{12,13}$ To identify the fungi which did not sporulate under the given conditions, they were kept under UV light for 1,3,6 and $12 \mathrm{~h}$ to activate their sporulating abilities. The identification of these fungal spp. were confirmed by comparing with reference cultures available at the Department of Biological Sciences, University of Calgary, Canada.

\section{Calculations}

Percentage frequencies of isolation of each fungal species were calculated as follows:

$\begin{aligned} & \% \text { frequencey } \\ & \text { of isolation }\end{aligned}=\frac{\text { No. of particles colonized }}{\text { Total No. of particles plated }} \times 100$

\section{RESULTS}

As indicated in Appendix 1, the highest frequency of isolation (21.7\%) was with Acremonium strictum and Trichothecium roseum from the freshly fallen leaves of $M$. nilagirica. $N$. coccinea and Broomella acuta were isolated in the higher frequencies of $19.17 \%$ and $14.17 \%$ respectively. Penicillium variabile (17.5\%) Broomella acuta (16.67\%), Cylindrocarpon magnusianum (12.5\%) and Alternaria tenuissima ( $11.67 \%$ ) were isolated from freshly fallen leaves of $S$. coriacea in higher frequencies. A. strictum, B. acuta, Dark sterile sp. $1, P$. variabile and $C$. magnusianum were the only fungal species commonly isolated from the freshly fallen stage of both leaf types.

Figure 2 shows the number of fungal spp. isolated from the different decomposition stages of the leaves of $M$. nilagrica and $S$. coriacea. In the case of freshly fallen leaves of both spp. a higher number of fungal spp. were isolated in lower frequencies. e.g. 18 fungal species from Michelia and 14 fungal species from Semecarpus were isolated in percentage frequencies of $0-4 \%$ whereas 4 and 9 fungal spp., respectively from Michelia and Semecarpus freshly fallen leaves, were isolated in 4.1-16\% frequencies. Three fungal spp. from Michelia and 2 fungal spp. from Semecarpus leaves were isolated in 16.1-64\% frequencies. No fungal species were isolated from either spp. in a percentage frequency greater than $64 \%$.

Among the fungi isolated from the $1^{\text {st }}$ decomposition stage of $M$. nilagrica. B. acuta was isolated in the highest frequency of $(36.67 \%)$. Trichoderma viride, Cladosporium sphaerospermum, Trichoderma pseudokoningii and Hyaline sterile sp. 16 were also isolated in the higher frequencies of $25.83 \%, 18.33 \%, 17.5 \%$ and $16.67 \%$ respectively. $B$. acuta was isolated in the highest frequency $(44.17 \%)$ from the $1^{\text {st }}$ decomposition stage of Semecarpus. The other fungal spp. isolated in higher frequencies from $S$. coriacea were Mortierella vinacea (16.67\%), Fusarium sp. 3 (12.5\%), Hyaline sterile sp.21 (12.5\%), Nodulosporium sp. 2 (10.83\%) and Cladosporium cladosporioides (10.83\%). B. acuta and $T$. viride were the fungal species isolated from both leaf types at the $1^{\text {st }}$ decomposition stage (Appendix 1). 
The frequency distribution classes of the fungal community in Figure 2 shows that the fungal species from the $1^{\text {st }}$ decomposition stage of both leaf types were isolated mostly in the lower frequencies. Seventeen fungal species from Michelia and 10 fungal species from Semecarpus were isolated in frequencies of $0-4 \% .10$ and 17 fungal species were isolated from Michelia and Semecarpus leaf litter respectively in frequencies of 4.1-16\%. Only 5 fungal spp. from Michelia and 2 fungal species from Semecarpus were isolated in the frequencies of $16.1-64 \%$. No fungal spp. were isolated in a mean percentage frequency higher than $64 \%$.

As indicated in Appendix 1, T. viride was isolated in the highest percentage frequency $(58.83 \%)$ from the $2^{\text {nd }}$ decomposition stage of $M$. nilagirica. Dark sterile sp. 17 (39.17\%), Curvularia lunata (33.33\%), Dark sterile sp. 15 (28.33\%), Trichoderma harzianum (27.5\%) and Cladosporium cladosporioides (25.83\%) were the other fungal spp. isolated in higher frequencies from this stage. $B$. acuta was isolated in the highest percentage frequency $(57.5 \%)$ from the $2^{\text {nd }}$ decomposition stage of $S$. coriacea leaf litter whereas $T$. viride, $M$. vinacea, $C$. cladosporioides, Pseudobotrytis terrestris and Trichoderma piluliferum were also isolated in higher frequencies $(35.8 \%, 25 \%, 25 \%, 21.67 \%$ and $19.17 \%$ respectively. $B$. acuta, $C$. cladosporioides, $N$. coocinea, $T$. piluliferum and $T$. viride were the commonly isolated species from both leaf litter types.

As seen in Figure 2 fungal spp. from the $2^{\text {nd }}$ decomposition stage of both leaf types were isolated in lower frequencies as well as higher frequencies. e.g. 9, 12 and 9 fungal spp. from Michelia were respectively isolated in frequencies of $0-4 \%, 4.1-16 \%$ and $16.1-64 \%$ respectively whereas 3, 5 and 8 fungal spp. were isolated from Semecarpus leaf litter in the frequencies of $0-4 \%$, $4.1-16 \%$ and $16.1-64 \%$ respectively. No fungal spp. were isolated in the frequencies greater than $64 \%$ from either leaf type.

From the 3rd decomposition stage of Michelia leaf litter, $C$. cladosporioides and $T$. piluliferum were isolated in the highest percentage frequencies of $87.49 \%$ and $87.5 \%$ respectively. $B$. acuta $(86.66 \%)$, Dark sterile sp.
27 (64.17\%), Cylindrocapon didymum (41.67\%), C. lunata $(37.5 \%)$ and $T$. viride $(35.83 \%)$ were isolated in higher frequencies. From the $3^{\text {rd }}$ decomposition stage of Semecarpus leaf litter, $T$. viride was isolated in the highest frequency $(65 \%)$. Hyaline sterile sp. 29, Rhizopus sp.1, Aspergillus sp.3 and Trichoderma sp.1 were the other dominant fungal spp. isolated with the frequencies $60.8 \%, 57.5 \%, 50.84 \%$ and $49.17 \%$ respectively. $T$. piluliferum, C. cladosporioides, B. acuta, C. lunata and $T$. viride were commonly isolated with different frequencies of occurrence from both leaf types. (Appendix 1).

With reference to the frequency distribution classes of the fungal communities shown in the Figure 2, most of the fungal spp. from the $3^{\text {rd }}$ decomposition stage of both leaf types were isolated in higher frequencies. No fungal spp. from Michelia leaf litter were isolated in the frequency of $0-4 \%$ and only 3 fungal spp. were isolated between the frequencies of $4.1-16 \%$. In Semecarpus leaf litter only one fungal spp. was isolated in the frequencies $0-4 \%$ whereas one was isolated in $4.1-16 \%$ frequency. Five and 4 fungal spp. from Michelia leaf litter were isolated in the frequencies 16.1-64\% and greater than 64\% respectively whereas 11 and 1 fungal species from Semecarpus leaf litter were isolated respectively in the frequencies of $16.1-64 \%$ and greater than $64 \%$.

It was clearly observed that there was an increase of the isolations of fungal species common to both leaf types with the advancement of litter decomposition.

\section{DISCUSSION}

The results obtained for the fungal community structure and its changes during the 4 analogous decomposition stages (freshly fallen, $1^{\text {st }}, 2^{\text {nd }}$ and $3^{\text {rd }}$ ) of $M$. nilagirica and $S$. coriacea leaf litter indicated the presence of certain fungal species (A. strictum, B. acuta, Dark sterile sp. 1, C. cladosporioides, $N$. coccinea, $T$. piluliferum, $T$. viride.....etc.) that was common to all four stages and other fungal species specific to the four decomposition stages of the two leaf types. Leaf materials of freshly fallen and $1^{\text {st }}, 2^{\text {nd }}$ and $3^{\text {rd }}$ decomposition stages of both leaf types are present in the $\mathrm{L}, \mathrm{L}^{1}, \mathrm{~F}^{1}$ and $\mathrm{F}^{2}$ layers respectively of the 


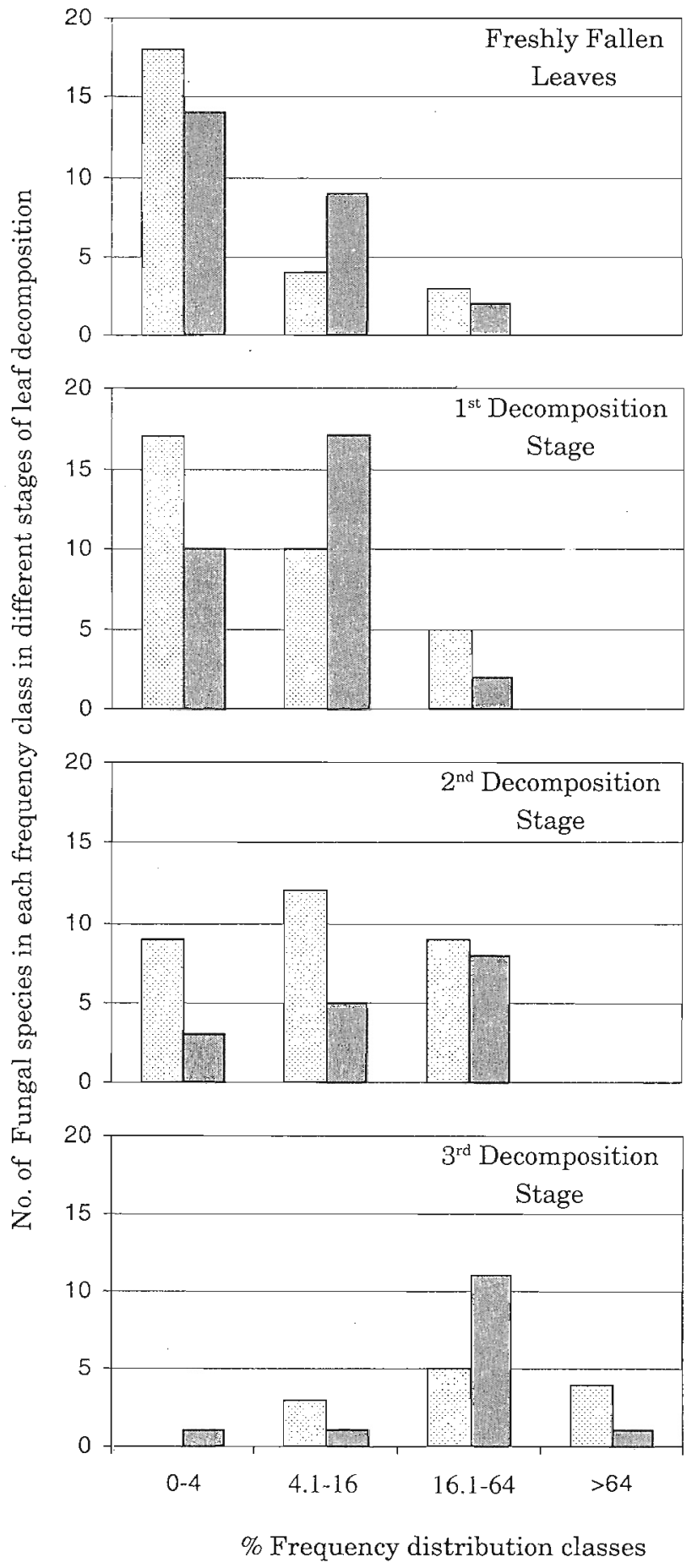

Figure 2: Frequency distribution classes of the fungal community in different stages of leaf decomposition of Michelia nilagirica and Semecarpus coriacea.

forest floor materials. Fungal succession on fallen leaves of Quetus, Betula and Fraxinus in a broad leaved UK woodland on mull humus, (until macroscopic leaf structure was lost) has shown differences between the four litter types. ${ }^{14}$ The differences between these succession patterns were largely due to the differences in resource quality such as nitrogen content and the presence of inhibitory tannin concentrations. A comparative study on fungal succession and microbes on leaf litter (Ageratum conizoides, Mallotus philippinensis, Holarrhena antidysenterica and Vitex glabrata) in two degraded tropical forests on northeast India has also shown high variations 
in the fungal communities in the four litter types. ${ }^{15}$ In the present study, the occurrence of different fungal species in Michelia and Semecarpus leaf litter might be also due to the differences in the leaf quality. The effect of climatic conditions is similar on the fungal spp. active on both types of leaf litter. In the freshly fallen and $1^{\text {st }}$ decomposition stages, the occurrence of fungal species common to both leaf types increased during the latter decomposition stages. This could be due to the differences in the structural components in the freshly fallen and slightly decomposed leaves. In later stages of decomposition, the structural components become more or less similar and therefore a higher occurrence of fungal spp. common to both leaf types was observed.

Many of the studies on fungal succession on leaf litter have been carried out in climatic and geographical regions different to those from Sri Lanka. Therefore it is not very appropriate to compare the results obtained in the present study with the observations made from such studies. However the study on the fungal succession on Aspen poplar leaf litter in Kananaskis valley in the front range of rocky mountain in Canada where the mean annual temperature is $4^{\circ} \mathrm{C}$, showed the presence of Aureobasidium pullulans only on live leaves. Other than this Cladosporium spp. including $C$. cladosporioides and $C$. sphaerospermum were observed in the live leaves and litter on the L layer and Mortierella spp. were observed in the litter of $F$ layers. ${ }^{16}$ Studies on the micro fungi of decomposing red alder leaves in a forest north of Copenhagen showed the occurrence of Aureobasidium spp. in the early and middle stages of the decomposition process. Cladosporium spp. including C. cladosporioides persisted throughout the decomposition process of the Alder leaves. Mortierella spp. appeared from the middle of the decomposition process and persisted to the latter decomposition stages. ${ }^{8}$ As in the case of these studies, in the present study too Aureobasidium spp. were seen only in the early stages (freshly fallen and $1^{\text {st }}$ decomposition stage) of Michelia leaf litter which are in the L layer of the forest floor materials but were not observed in the fungal succession on Semecarpus leaf litter. In the present study too, Cladosporium spp. especially C. cladosporioides were observed in several of the decomposition stages of both Michelia and Semecarpus leaf litter and Mortierella sp. (M. vinacea) was isolated from the later decomposition stages of Semecarpus leaf litter. Although the presence of Acremonium spp. was observed throughout the decomposition stages of Aspen leaves ${ }^{16}$, in the present study isolation of Acremonium spp. were made only from early decomposition stages of both leaf types.

Fungal succession studies carried out in India, have reported the occurrence of many Aspergillus and Penicillium spp. throughout the process of decomposition of different plant litter. Isolation of eight Aspergillus spp. were reported from the different decomposition stages of Chenopodium album leaf litter. ${ }^{17}$ Four Aspergillus spp. were frequently isolated from decomposing materials of sugar cane bagasses. ${ }^{18}$ Three Aspergillus spp. and five Penicillium spp. were frequently isolated from many of the decomposition stages of Mallotus leaf litter. In the decomposing leaves of Holarrhena antydysentrica and Vitex glabrata leaf litter, Penicillium chrysogenum and Aspergillus niger were the most dominant fungal spp. occurring during the succession..$^{15}$ In the present study the occurrence of Aspergillus spp. and Penicillium spp. in the decomposing leaves of both types was very low. One Aspergillus spp. was isolated in high frequency $(50.84 \%)$ only from the $3^{\text {rd }}$ decomposition stage of Semecarpus and only four Penicillium spp. were isolated occasionally except for Penicillium variabile.

According to the frequency distribution classes of the fungal communities in the four decomposition stages (Figure 2) it was clearly observed that the fungal isolations from the early decomposition stages of both leaf types occurred in lower frequencies. With the advancement of litter decomposition the fungal isolations occurred in higher frequencies from both leaf litter types. The distribution of fungal species present in the freshly fallen leaves and the leaves in decomposition stage 1 , of both leaf types may be localized into some areas of the leaves. However in the latter decomposition stages of both leaf types, their distribution may be more or less even over the leaf surface in both leaf types. Therefore, this could be the reason for their isolation in lower 
frequencies from the early decomposition stages and isolation in higher frequencies from the latter decomposition stages of both leaf types.

From the present study it is clear that $B$. acuta, C. cladosporioides, C. lunata, N. coccinea, $T$. piluliferum and $T$. viride were the dominant fungal spp. isolated from several decomposition stages of both leaf types with higher frequencies. Among them $B$. acuta was the most dominant fungal spp. isolated from all 4 decomposition stages of both leaf types with higher frequencies. These fungal spp. may have more competitive saprophitic abilities than the other litter inhabiting mycoflora in the Hakgala forest floor and also they may have versatile substrate utilization abilities to utilize many of the labile and non labile complex structural cell wall components.
This study reveals the pattern of succession in fungal communities and gives an insight to the nutrient turnover in the ecosystem. An additional advantage is that the identified fungal cultures isolated during this study could be used as reference cultures. Therefore in addition to maintaining the live cultures, a database could be maintained where all the information on this collection of fungal isolates is available.

\section{Acknowledgement}

Authors acknowledge the financial assistance provided by the Canadian International Development Agency grant through Kelaniya Calgary academic link programme.

\section{Appendix 1}

Percentage frequency of occurrence of the dominant fungal species at different stages (freshly fallen leaves (fresh stage), decomposition stages 1-3 (1 $1^{\text {st }}-3^{\text {rd }}$ stages) of Michelia nilagirica and Semecarpus coreacea, in the Hakgala Strict Natural Reserve.

\begin{tabular}{|c|c|c|c|c|c|c|c|c|}
\hline \multirow{2}{*}{$\begin{array}{l}\text { Dominant fungi in } \\
\text { different stages } \\
\text { of decomposition }\end{array}$} & \multicolumn{4}{|c|}{$\begin{array}{c}\text { Decomposing leaves of } \\
\text { Michelia nilagirica }\end{array}$} & \multicolumn{4}{|c|}{$\begin{array}{l}\text { Decomposing leaves of } \\
\text { Semecarpus coreacea }\end{array}$} \\
\hline & $\begin{array}{l}\text { Fresh } \\
\text { stage }\end{array}$ & $\begin{array}{c}1^{\text {st }} \\
\text { stage }\end{array}$ & $\begin{array}{c}2^{\text {nd }} \\
\text { stage }\end{array}$ & $\begin{array}{c}3^{\text {rd }} \\
\text { stage }\end{array}$ & $\begin{array}{l}\text { Fresh } \\
\text { stage }\end{array}$ & $\begin{array}{c}1^{\text {st }} \\
\text { stage }\end{array}$ & $\begin{array}{c}2^{\text {nd }} \\
\text { stage }\end{array}$ & $\begin{array}{c}3^{\text {rd }} \\
\text { stage }\end{array}$ \\
\hline Acremonium kilience & 2.5 & 13.33 & - & - & - & - & - & - \\
\hline Acremonium strictum & 21.67 & - & - & - & 7.5 & - & - & - \\
\hline Acremonium butyri & - & - & - & - & 1.67 & - & & - \\
\hline Acremonium sp.2 & - & - & - & - & - & 2.50 & - & - \\
\hline Alternaria tenuissima & - & 2.5 & - & & 11.67 & - & - & - \\
\hline Amorphotheca resinae & - & - & - & - & - & 5.0 & & - \\
\hline Aspergillus sp.1 & - & - & 0.83 & - & - & - & - & - \\
\hline Aspergillus sp.2 & - & - & 4.17 & & - & - & - & - \\
\hline Aspergillus sp.3 & - & - & - & - & - & - & - & 50.84 \\
\hline Aureobasidium sp.1 & 0.83 & - & - & - & - & - & - & - \\
\hline Aureobasidium sp.2 & - & 6.67 & - & - & - & - & - & - \\
\hline Basidiomycete sp.1 & 5 & - & - & - & - & - & - & - \\
\hline Basidiomycete sp.2 & - & - & 11.67 & - & - & - & - & - \\
\hline Botrytis cinerea & - & 2.5 & - & - & - & - & - & - \\
\hline Broomella acuta & 14.17 & 36.67 & 17.5 & 86.66 & 16.67 & 44.17 & 57.5 & 35.83 \\
\hline Chloridium clamydosporis & - & - & - & - & - & 10 & - & - \\
\hline Cladosporium cladosoprioides & 8.33 & - & 25.83 & 87.49 & - & 10.83 & 25 & 46.67 \\
\hline Cladosporium sphaerospermum & - & 18.33 & - & - & - & - & - & - \\
\hline Cladosporium sp.1 & - & - & - & 27.5 & - & - & - & - \\
\hline Cladosporium sp.2 & - & - & - & 10.83 & - & - & - & \\
\hline Coelomycete sp.1 & 0.83 & - & & - & - & - & - & - \\
\hline Coelomycete sp.2 & 1.67 & - & - & - & - & - & - & - \\
\hline Coelomycete sp.3 & - & - & - & - & 5 & - & - & - \\
\hline
\end{tabular}




\begin{tabular}{|c|c|c|c|c|c|c|c|c|}
\hline \multirow{2}{*}{$\begin{array}{l}\text { Dominant fungi in } \\
\text { different stages } \\
\text { of decomposition }\end{array}$} & \multicolumn{4}{|c|}{$\begin{array}{l}\text { Decomposing leaves of } \\
\text { Michelia nilagirica }\end{array}$} & \multicolumn{4}{|c|}{$\begin{array}{l}\text { Decomposing leaves of } \\
\text { Semecarpus coreacea }\end{array}$} \\
\hline & $\begin{array}{l}\text { Fresh } \\
\text { stage }\end{array}$ & $\begin{array}{l}1^{\text {st }} \\
\text { stage }\end{array}$ & $\begin{array}{c}2^{\text {nd }} \\
\text { stage }\end{array}$ & $\begin{array}{c}3^{\text {rd }} \\
\text { stage }\end{array}$ & $\begin{array}{l}\text { Fresh } \\
\text { stage }\end{array}$ & $\begin{array}{c}1^{\text {st }} \\
\text { stage }\end{array}$ & $\begin{array}{c}2^{\text {nd }} \\
\text { stage }\end{array}$ & $\begin{array}{l}3^{\text {rd }} \\
\text { stage }\end{array}$ \\
\hline Coelomycete sp.4 & - & 13.33 & - & - & - & - & - & - \\
\hline Curvularia lunata & - & 3.33 & 33.33 & 37.5 & - & - & - & 35.83 \\
\hline Cylindrocarpon didymum & - & 11.67 & - & 41.67 & - & - & - & - \\
\hline Cylindrocarpon paruum & - & - & - & - & - & 10 & - & - \\
\hline Cylindrocarpon magnusianum & 1.67 & - & - & - & 12.5 & - & - & - \\
\hline Cylindrocarpon sp.1 & - & 5.83 & - & - & - & - & - & - \\
\hline Cylindrocarpon sp.2 & - & - & - & - & - & 3.33 & - & - \\
\hline Cylindrocarpon sp.3 & - & - & 6.66 & - & - & 0.83 & - & - \\
\hline Cylindrocarpon sp. 4 & - & - & 5 & - & - & - & - & - \\
\hline Dark sterile sp. 1 & 4.17 & - & - & - & 5.83 & - & - & - \\
\hline Dark sterile sp. 2 & - & - & - & - & 8.33 & - & - & - \\
\hline Dark sterile sp. 3 & - & - & - & - & 2.5 & - & - & - \\
\hline Dark sterile sp. 4 & - & - & - & - & 2.5 & - & - & - \\
\hline Dark sterile sp. 5 & - & - & - & - & 0.83 & - & - & - \\
\hline Dark sterile sp. 6 & - & - & - & - & 2.5 & - & - & - \\
\hline Dark sterile sp. 7 & - & - & - & - & 1.67 & - & - & - \\
\hline Dark sterile sp. 8 & - & - & - & - & 10 & - & - & \\
\hline Dark sterile sp. 9 & - & 11.67 & - & - & - & - & - & - \\
\hline Dark sterile sp. 10 & - & - & - & - & - & 1.66 & - & - \\
\hline Dark sterile sp. 11 & - & - & - & - & - & 4.17 & - & - \\
\hline Dark sterile sp. 12 & - & - & - & - & - & 6.67 & - & - \\
\hline Dark sterile sp. 13 & - & - & - & - & - & 10 & - & - \\
\hline Dark sterile sp. 14 & - & - & - & - & - & 3.33 & - & - \\
\hline Dark sterile sp. 15 & - & - & 28.33 & - & - & - & - & - \\
\hline Dark sterile sp. 16 & - & - & 0.83 & - & - & - & - & - \\
\hline Dark sterile sp. 17 & - & - & 39.17 & - & - & - & - & - \\
\hline Dark sterile sp. 18 & - & - & 18.33 & - & - & - & - & - \\
\hline Dark sterile sp. 19 & - & - & 13.33 & - & - & - & - & - \\
\hline Dark sterile sp. 20 & - & - & 5.83 & - & - & - & - & - \\
\hline Dark sterile sp. 21 & - & - & 1.67 & - & - & - & - & - \\
\hline Dark sterile sp. 22 & - & - & 24.17 & - & - & - & - & - \\
\hline Dark sterile sp. 23 & - & - & 3.33 & - & - & - & - & - \\
\hline Dark sterile sp. 24 & - & - & 9.17 & - & - & - & - & - \\
\hline Dark sterile sp. 25 & - & - & - & - & - & - & 9.17 & - \\
\hline Dark sterile sp. 26 & - & - & - & - & - & - & 25 & - \\
\hline Dark sterile sp. 27 & - & - & - & 64.17 & - & - & - & - \\
\hline Dark sterile sp. 28 & - & - & - & - & - & - & - & 38.33 \\
\hline Dark sterile sp. 29 & - & - & - & - & - & - & - & 45.83 \\
\hline Diheterospora catenulata & 3.33 & - & - & - & - & - & - & - \\
\hline Fusarium acuminata & - & - & - & - & 0.83 & - & - & - \\
\hline Fusarium sporotrichioides & - & - & - & - & - & 5 & - & - \\
\hline Fusarium sp.1 & - & - & 0.83 & - & - & - & - & - \\
\hline Fusarium sp.2 & - & 1.67 & - & - & - & - & - & - \\
\hline Fusarium sp.3 & - & - & - & - & - & 12.5 & - & - \\
\hline Fusarium sp.4 & - & - & 4.17 & - & - & - & - & - \\
\hline Fusarium sp.5 & - & - & 3.33 & - & - & - & - & - \\
\hline Fusarium sp. 6 & - & - & 0.83 & - & - & - & - & - \\
\hline Fusarium sp.7 & - & - & - & 16.67 & - & - & - & - \\
\hline Geotrichum candidum & - & - & - & - & - & 5.83 & 6.67 & - \\
\hline
\end{tabular}




\begin{tabular}{lcccccccc}
\hline & \multicolumn{3}{c}{ Decomposing leaves of } & \multicolumn{3}{c}{$\begin{array}{c}\text { Decomposing leaves of } \\
\text { Dominant fungi in }\end{array}$} & \multicolumn{3}{c}{ Michelia } & nilagirica & \multicolumn{3}{c}{ Semecarpus coreacea } \\
\cline { 2 - 9 } $\begin{array}{l}\text { different stages } \\
\text { of decomposition }\end{array}$ & Fresh & $1^{\text {st }}$ & $2^{\text {nd }}$ & $3^{\text {rd }}$ & Fresh & $1^{\text {st }}$ & $2^{\text {nd }}$ & $3^{\text {rd }}$ \\
\hline
\end{tabular}

Gliomastix sp.1

Gliocladium catenulatum

Glomerella cingulata

Hyaline sterile sp.1

Hyaline sterile sp.2

Hyaline sterile sp. 3

Hyaline sterile sp.4

Hyaline sterile sp. 5

Hyaline sterile sp.6

Hyaline sterile sp.7

Hyaline sterile sp. 8

Hyaline sterile sp.9

Hyaline sterile sp.10

Hyaline sterile sp.11

Hyaline sterile sp.12

Hyaline sterile sp.14

Hyaline sterile sp.15

Hyaline sterile sp.16

Hyaline sterile sp.17

Hyaline sterile sp.18

Hyaline sterile sp.19

Hyaline sterile sp.20

Hyaline sterile sp.21

Hyaline sterile sp.22

Hyaline sterile sp.23

Hyaline sterile sp. 24

Hyaline sterile sp.25

Hyaline sterile sp. 26

Hyaline sterile sp.27

Hyaline sterile sp.28

Hyaline sterile sp.29

Hyaline sterile sp. 30

Mortierella vinacea

Mucor sp.1

Myrothesium sp.1

Nectria coccinea

Nectria sp.2

Nodulosporium sp.1

Nodulosporium sp.2

Nodulosporium sp.3

Penicillium variabile

stage stage stage stage

9.17

Penicillium sp. 1

Penicillium sp.2

Penicillium sp.3

Penicillium sp.4

Phialophora sp.1

-
-
-
1.67
1.67
2.5
2.5
1.67
2.5
1.67
2.5

-

11.67

8.33

1.67

2.5

2.5

1.67

2.5

1.67

2.5

Phialophora sp.2

Phialophora sp.3

Phialophora sp.4 


\begin{tabular}{|c|c|c|c|c|c|c|c|c|}
\hline \multirow{2}{*}{$\begin{array}{l}\text { Dominant fungi in } \\
\text { different stages } \\
\text { of decomposition }\end{array}$} & \multicolumn{4}{|c|}{$\begin{array}{l}\text { Decomposing leaves of } \\
\text { Michelia nilagirica }\end{array}$} & \multicolumn{4}{|c|}{$\begin{array}{l}\text { Decomposing leaves of } \\
\text { Semecarpus coreacea }\end{array}$} \\
\hline & $\begin{array}{l}\text { Fresh } \\
\text { stage }\end{array}$ & $\begin{array}{c}1^{\text {st }} \\
\text { stage }\end{array}$ & $\begin{array}{c}2^{\text {nd }} \\
\text { stage }\end{array}$ & $\begin{array}{c}3^{\text {rd }} \\
\text { stage }\end{array}$ & $\begin{array}{l}\text { Fresh } \\
\text { stage }\end{array}$ & $\begin{array}{c}1^{\text {st }} \\
\text { stage }\end{array}$ & $\begin{array}{c}2^{\text {nd }} \\
\text { stage }\end{array}$ & $\begin{array}{l}3^{\text {rd }} \\
\text { stage }\end{array}$ \\
\hline Pithomyces sp.1 & - & - & - & 14.17 & - & - & - & - \\
\hline Pseudobotrytis terrestris & - & - & - & - & - & - & 21.67 & 42.5 \\
\hline Rhizopus sp.1 & - & - & - & - & - & - & - & 57.5 \\
\hline Scolecobasidium sp.1 & 2.5 & - & - & - & - & - & - & \\
\hline Steptonema sp.1 & 3.33 & - & - & - & - & - & - & - \\
\hline Trichoderma hamatum & - & 5 & - & - & - & - & 10.01 & - \\
\hline Trichoderma harzianum & - & 3.33 & 27.5 & - & - & - & - & - \\
\hline Trichoderma koningii & - & - & - & - & - & 3.33 & - & - \\
\hline Trichoderma piluliferum & - & - & 6.67 & 87.5 & - & - & 19.17 & 13.33 \\
\hline Trichoderma pseudokoningii & - & 17.5 & 5.83 & - & - & & - & - \\
\hline Trichoderma viride & - & 25.83 & 55.83 & 35.83 & - & 8.33 & 35.83 & 65 \\
\hline Trichoderma sp.1 & - & - & - & - & - & 6.67 & - & 49.17 \\
\hline Trichothecium roseum & 21.67 & - & - & - & - & - & - & - \\
\hline Unidentified sp.1 & 2.5 & - & - & - & & - & - & - \\
\hline Unidentified sp.2 & - & - & - & - & 3.33 & - & - & - \\
\hline Unidentified sp.3 & - & - & - & - & - & - & 2.5 & - \\
\hline $\begin{array}{l}\text { Total number of spp. } \\
\text { recorded at each stage }\end{array}$ & 25 & 30 & 31 & 12 & 25 & 28 & 15 & 14 \\
\hline
\end{tabular}

\section{References}

1. Wijesundara D.S.A., Gunatilleke C.V.S. \& Gunatilleke I.A.U.N. (1985). Summit vegetation of the Hakgala strict natural reserve. Proceedings of the Annual Sessions of the Sri Lanka Association for the Advancement of Science 102-105.

2. Maggs J. (1985). Litter fall and retranslocation of nutrients in a refertilized and prescribed burned Pinus elliottil plantations. Forest Ecology \& Management 12: 253-268.

3. Weerakkody W.J.S.K. (1994). Litter and microbial biomass dynamics in an upper montane rain forest in Sri Lanka. Ph.D thesis. Faculty of Science, University of Kelaniya.

4. Swift M.J., Heal O.W. \& Anderson J.M. (1979). Decomposition in terrestrial ecosystem. Blackwell Scientific Publications, London.

5. Visser S. (1985). Role of the soil invertebrates in determining the composition of soil microbial communities. In: Ecological interactions in soil. (Eds. A.H. Fitter, D. Atkinson, D.J. Read \& M.B Usher) pp.297-317. Blackwell Scientific Publications, Oxford.
6. Cortez J.M., Demard P., Bottner \& Monrozier. (1996). Decomposition of Mediterranean leaf litter: A microcosm experiment investigating relationships between decomposition rates and litter quality. Soil Biology \& Biochemistry 28: 443-452.

7. Kjoller A. \& Struwe S. (1992). Functional groups of microfungi in decomposition. In: Fungal community. Its organization and role in the ecosystem. (Eds. C. George, Carroll \& Donald) pp: 619-630. Marcel Dekker. New york. Hong Kong.

8. Kjoller A. \& Struwe S. (1980). Microfungi on decomposing Red Alder leaves and their substrate utilization. Soil Biology \& Bio Chemistry 28: 443-452.

9. Harley J.L. \& Waid J.S. (1955). A method of studying active mycelia on living roots and the surface in soil. Trans Actions of British Mycological Society 38: 104-118.

10. Kannangara B.T.S.D.P., Deshappriya N., Gunesekera S.A. \& Parkinson D. (1996). Determination of washing efficiencies for leaf 
litter of Michelia nilagirica and Semecarpus coriacea. Proceedings of the $52^{\text {nd }}$ Annual Sessions of the Sri Lanka Association for the Advancement of Science 66-67.

11. Flegel T.W. (1980). Semi permanent microscope slides of microfungi using sticky tape technique. Canadian Journal of Microbiology 26: 551-553.

12. Barron G.L. (1983). The Genera of Hypomycetes from soil. Robert E. Krieger Company, Malber, Florida.

13. Domsch K.H., Gams W. \& Andeson T.L. (1993). Compendium of Soil Fungi. Vol. 1 and 2. London. New York. Academic Press.

14. Frankland J.C. (1998). Fungal succession. Unraveling the unpredictable. Mycological research 102(1): 1-15.
15. Kshasttriya S., Sharma G.D. \& Mishra R.R. (1994). Fungal succession and microbes on leaf litters in two degraded tropical forests. Pedobiologia 38: 125-137.

16. Visser S. \& Parkinson D. (1975). Fungal succession on Aspen Poplar leaf litter. Canadian Journal of Botany 53: 1640-1651.

17. Mehrotra R.S. \& Aneja K.R. (1979). Microbial decomposition of Chenopodium album litter. Succession of decomposers. Journal of Indian Botanical Society 58: 189-195.

18. Sandhu D.K. \& Sidhu M.S. (1980). The fungal succession on decomposing sugar cane bagasse. Trans action of the British mycological Society $\mathbf{7 5}(2)$ : 281-282. 